\title{
The Khilafah Discourse on Aljazeera and Alarabiya: a Valuable Lesson for Indonesian Online Media
}

\author{
Moch. Syarif Hidayatullah \\ Translation Department \\ Faculty of Adab and Humanities \\ Syarif Hidayatullah State Islamic University Jakarta \\ Jakarta, Indonesia \\ moch.syarifluinjkt.ac.id
}

\author{
Yuliani \\ Magister Program on Arabic Language and Literature \\ Faculty of Adab and Humanities Syarif Hidayatullah State \\ Islamic University Jakarta \\ Jakarta, Indonesia \\ yulianiyulianil4@mhs.uinjkt.ac.id
}

\begin{abstract}
The study conducted on this thesis aims to reveal the online media ideology of Aljazeera and Alarabiya in presenting the news about Khilafah discourse, especially after the Islamic State of Iraq and Syria (ISIS) in 2014. This study uses the theory of critical discourse analysis model Norman Fairclough which suggests that discourse is a social practice. This research uses analyzing the text, practice of discourse, and social practice. The results of this study indicate that the media Aljazeera and Alarabiya put Khilafah discourse as a movement, not a country. But Aljazeera media using vocabulary related to the political history of Islam which was built in the 7th century. In contrast to Alarabiya that did not mention the history of the Caliphate. The ideology used by both Arab media is PanArabian ideology, but the ideology is not pure Pan-Arab because Aljazeera with its Arabic discusses the Khilafah discourse as part of Arabic history, while the pro-American Alarabiya does not discuss terminology Khilafah related to the state. The ideology of both media is also inseparable from the political interests of the country that funded the Qatar and Saudi Arabia.
\end{abstract}

Keywords - Khilafah, Critical Discourse Analysis, Mass Media Ideology, Indonesian Online Media

\section{INTRODUCTION}

After the declaration of Iraq and Sham (ISIS) in Ramadan $1435 \mathrm{H}$ or 29 June 2014 , the mass media both online and print in Indonesia, competing to make news about ISIS, how it relates to Indonesia, who are people in Indonesia who joined him, to the discourse of Khilafah that made conversation. Then Khilafah discourse grew after Australian AttorneyGeneral George Brandis said Australia issued a warning that ISIS is redoubled its presence in Indonesia with the dream of establishing "Khilafah Far" in the world's most populous Muslim country (Antaranews.com, 31 Maret 2016).

Amid the current era of globalization, the media has its own role in conveying the discourse to the reader. Media is the main source for the public to know the information related to the reality that is happening. The media plays a role in defining how reality should be understood, how it is explained in some way to the public $[1$, p. 122]. From here Khilafah discourse was kept rolling, not only in the print media but also in online media. The war of paradigm against Khilafah discourse arose in the midst of society. Besides, the public is faced with the fact that ISIS violence is considered a representation of the Khilafah as a form of Islamic political institution. The war of paradigm continues through online media. Any text that appears in the preaching of Khilafah hides or implements the implicit ideology of the speakers of the text. The media has its own ideological perspective affecting the content of the news, therefore it obtains a balance of information. Therefore, we choose Arabic news media Aljazeera which its emergence is also part of the resistance to Western media domination. Aljazeera has a spirit of information disclousure that treathens Western domination ti continue feeding the world with news corresponding to their national interests. In addition to Arabic media Aljazeera (aljazeera.net), we will also analyze Alarabiya news website (alarabiya.net) who became competitors in the Arab world news.

\section{METHOD}

The study of the Khilafah discourse in Arabic online media coverage focuses on the use of diction in the text of its preaching. The method used is qualitative descriptive with the critical perspective of Fairclough model. The critical language analysis of its essence can be seen by looking at the grammar of the language used so that it can reveal the ideology behind a discourse, because with language, either by its word choice or by its grammatical language able to express a certain ideological meaning.

Social practices, dimensions related to context outside the text; such as the context of the situation or the context of the media in relation to a particular society or political culture [2, p. 66]. The social context outside the media influences how discourse arises in the media. Fairclough makes three levels of analysis on sociocultural practice, in situational, institutional, and social levels [1, p. 322]. In situational levels the news text is produced under typical conditions and circumstances, so the possibility of one news text is differe nt from other news texts for one case. Then at the institutional level discussed the influence of organizations in producing discourse, such as advertising, rating or circulation, and competition between media. While at the social level that the discourse appears in the media is determined by the factor of social change, in the social level of social change will 
determine the development of media discourse.

Fairclough stated that the process of this text analysis as microlevel, discourse practice as mesolevel, and the process of analysis of sociocultural practice as a macrolevel [3]. Discourse analysis using a critical approach shows cohesiveness: text analysis; process analysis, production, consumption, and distribution of text; as well as the sociocultural analysis that developed around the discourse [4, p. 98]. The analysis of critical discourse according to Fairclough is an integrative activity of analyzing the three dimensions (text, a practice of discourse, and social practice) because it is a unity that cannot be separated from one another [4, p. 98].

\section{RESULT AND DISCUSSION}

In order to understand the construction of texts built by Arab online media, we used the keyword "al-khilafah alislamiyah" to get news releted to khalifah discourse. With these keyword, we found from each online media as much as 70 news after ISIS declaration in 2014. In this paper, we only highlight three main topics: (1) Khalifah and terrorism; (2) Khilafah as organization or instruction; (3) Khilafah, ideology, and hegemony.

On Khalifah and terrorism, Aljazeera in its news report calls the perpetrators of the khilafah declaration as $a$;-jama'ah al-mutatharrifah (extremist group), al-musallahun (militants), and al-mutatharrifin al-sunnah (Sunni Extremist). While Al Arabiya uses jama'ah musallahah (militant group), almutasyaddin al-islamiyyin (militant Islam), mutasyaddidin muqatilin islamiyyin (militant Islamic fighter), al-irhabi (terrorist), jadzri (radical), al-'anif (cruel). The use of the word used by Aljazeera is more neutral than the tendentious Al Arabiya even calling militant Islmist militants to represant terorist. Not only that Alarabiya also linked the activities of the actors of the declaration of khilafa with $\mathrm{Al}$ Qaeda, which is a group very attached to the image of terrorism. The editors of Aljazeera say that the Khalifa declared by ISIS is the Islamic caliphate which was in effect in the seventh century $\mathrm{AD}$ if Aljazeera sees the Khalifah discourse as part of Arab history different from $\mathrm{Al}$ Arabiya which relates the declaration of Khalifah as a series of terror events that occurred since 911.

About Khilafah as an organization or institution, an interesting representation that appears in both Arabic online media is the placement of the declaration of ISIS as a movement or organization, it is seen from the use of vocabulary. Aljazeera calls the actors of the Khilafah declaration tanzhim al-daulah (the state organization), tanzhim al-daulah al-islamiyyaf fi al-Iraq wa al-Syam (the ISIS organization), muqatilu al-tanzhim (organization fighter). While Alarabiya calls it by al-tanzhim al-irhabi (the terrorist organization), al-tanzhim al-jihadi (the jihadist organization), tanzhim da isy (the ISIS organization). The use of vocabulary used by Aljazeera tends to lead the opinions of the readers to see that the Khilafah is merely the activity of a movement that wants the establishment of a Khilafah like the seventh century AD. While Alarabiya saw that the declaration of the caliphate was the activity of the terrorist movement.
About Khilafah, ideology, and hegemony, the existence of a hidden ideology moves behind the discourse of Khilafah and discourse practice, in this case is discussed the practice of discourse raised by Aljazeera and Alarabiya. The existing discourse practices are khalifah, terrorism, and terrorist movements. Furthermore, because it is attached to the practice of discourse, ideology can be more effective if its existence is naturalized to become common sense [4, p. 89]. The practice of caliphate discourse is associated with allegiance to Abu Bakr Al-Baghdady which was claimed by the deceased caliphate as the Muslim caliph. The perpetrator also explained that Muslims should immediately declare their allegiance to the Caliph of Al-Baghdady. But Alarabiya's editorial in his news report reveals the background of Al-Baghdady who once had ties with Abu Musab al-Zarqawi and Osama bin Laden who is a former Al-Qaeda leader.

The practice of the caliphate discourse discussed by the editors of Alarabiya leads to the practice of terrorist discourse, not just Abu Bakr al-Baghdady's personalities linked to terrorists but the perpetrators as a group are also linked to terrorism. The emergence of ISIS as the actor of the declaration of the caliphate was also called by the editors as a series of activities of the 911 attack. In contrast to Alarabiya, Aljazeera discusses the Khilafah discourse related to Arab history in the 7th century AD, Aljazeera also discusses the video footage uploaded by the perpetrator, entitled kasr alhudud (breaking the border). The video has a meaning that is in line with the name change of the actor who originally aldaulah al-islamiyyah fi al-iraq wa al-syam (ISIS) became (the Islamic state). The discussion of the video entitled kasr al-hudud (breaking the border) is increasingly convincing that the offender wants to eliminate the boundaries of nation-state. These national state boundaries that ISIS claims will be destroyed (Gulfnews.com, 30 January 2013).

The growing understanding of the nation-state (state nation) after the collapse of the Khilafah also clash of discourse, between the Khilafah and nation-state. Historically the concept of a nation-state born and emerging in Europe, the concept emerged as a form of resistance to the feudal system (monarchy) that existed at the time. and growing up after the Nuremberg peace treaty of 1648 . The concept of the nationstate became the determinant of the European geopolitica 1 structure. In modern times the term nation-state is often used to denote the identity of almost every country today. The form of a nation-state became a popular choice for Muslim countries after the first world war. The nation-state also became a trend in modern times and became the choice of Muslim countries after colonization and colonialism.

The idea of a nation-state began to enter Islamic political thought alongside the entry of other European political ideas, the concept of a nation-state began to be propagandized as a form of love of the homeland. Tahtawi (1801-1873 AD) argued that a person from the same land of water had the same duty to one another, just as one person's relationship with another in the same religion [5, p. 620]. Lutfi al-Sayyid (1872-1963) had the idea that 'Islamic land is the homeland of all Muslims', and it relates to the Ottoman Khilafah 
Government. According to him the idea is outdated and must be replaced with a belief that is in accordance with the ambitions of each Eastern country that has a certain homeland is a sense of nationalism [5, p. 620]. Gramsci's hegemonic theory emphasizes that in the social field there is a struggle for public acceptance, therefore, it is necessary for the dominant group to spread its ideology and truth to accept, without resistance [1, p. 107].

According to Fairclough--who also adopted the Gramsci hegemony theory--the concept of hegemony gives us a tool that we can use to analyze how discourse practices become part of widespread social practice involving power relations: the practice of discourse can be seen as a hegemonic aspect of struggle that contributes to reproduction and the transformation of the order of discourse which is its part (and consequently also the existing power relations) [2, p. 142]. Hegemony works through consensus rather than attempting to suppress one group against another. One of the strengths of hegemony is how it creates a dominant way of thinking or discourse, which is assumed to be true, while other discourses are considered wrong. There is one value or consensus that is assumed to be true, so that when any other point of view or discourse is regarded as incorrect. The media here can inadvertently become the means by which the dominant values or discourses are disseminated and seeped in the minds of the audience in order to be mutual consensus, while other values or discourses are seen as distorted [4, pp. 71-83]. It is the consensus that makes the people submit and obey voluntarily or not to the dominant ideology. Here is the media Aljazeera and Alarabiya trying to build an opinion about the link between the caliphate with terrorism, terrorism movements, and Arab history.

Western news agencies - such as Reuters and AFP (Agence France Presse) - are also a source of news for Arab media, not least Aljazeera and Alarabiya. Today most of the reports on other countries come from the central state (superpowers). Then finally dictate the reach of news and impose the representation of other countries in accordance with the dominant global discourse. Hence global news "domestication" is believed to strengthen existing political hegemony [6].

The incessant discourse of this WOT makes Muslim countries cornered and accused as a party who likes to spread terror and violence, a radical attitude into a label intended for Muslims in general. No exception about the Khilafah discourse with the emergence of ISIS which is considered as terror and threat to the world.

\section{CONCLUSION}

Although Aljazeera and Alarabiya claim to be news sites representing the Middle East region, the existence of interests, alignments, and ideology have an influence in the production of news. In the end, the Aljazeera news agency remains largely representative of Middle Eastern interests and sensibilities, hence it can be concluded that the ideology of the Aljazeera news website is Pan-Arabism which leads to the nationalism of the own country. The ideology that emerges in the preaching of Khilafah is not pure pan-Arab, as the emerging Arab feelings are also part of the resistance to US hegemony and domination that often corners Islam represented in the Arab world in general. The stigma that Aljazeera is an anti-mainstream news site to the discourse brought by the West seems inherent as an identity for Aljazeera. While Alarabiya herds the Khilafah discourse to the dominant global discourse of War on Terrorism which is intensified West.

The fact is a valuable lesson for many Indonesian mass media. In the news, the media is inseparable from the agenda and interests of the owners. But the truth is not sacrificed for the short term because every time always has a mechanism to end it. Today the mass media is being threatened by the presence of social media. If the mass media (especially Indonesian online media) does not immediately clean up, it is not impossible for the next few years the mass media will be abandoned by the readers. In preaching, the media should have to consider the principle of cover both side and impact for the object being preached.

\section{REFERENCES}

[1] Eriyanto, AnalisisFraming: Konstruksi, Ideologi, dan Politik Media. Yogyakarta: LkiS, 2002.

[2] M. W. Jorgensen and Louise J. Phillips, Analisis Wacana Teori dan Metode. Yogyakarta: Pustaka Pelajar, 2010.

[3] A. Scott, Sorensen and Charlotte Krolokke, Gender Communication Theories and Analyses. California: Sage Publication, 2006.

[4] N. Fairclough, Discourse and Social Change. Cambridge: Polity Press, 1995.

[5] A. Black, Pemikiran Politik Islam, dari Masa Nabi hingga Masa Kini. Jakarta: Serambi, 2001.

[6] D. Kishan Thussu, "Managing the Media in a Era of Round-the-Clock News: notes from India's First Telewar”. Jurnalism Studies, pp. 203212 . 